ARTICLE

Received 26 Nov 2012 | Accepted 25 Feb 2013 | Published 3 April $2013 \quad$ DOI: 10.1038/ncomms2659

\title{
Reconciliation of marine and terrestrial carbon isotope excursions based on changing atmospheric $\mathrm{CO}_{2}$ levels
}

Brian A. Schubert ${ }^{1, \dagger} \&$ A. Hope Jahren ${ }^{1}$

Negative carbon isotope excursions measured in marine and terrestrial substrates indicate large-scale changes in the global carbon cycle, yet terrestrial substrates characteristically record a larger-amplitude carbon isotope excursion than marine substrates for a single event. Here we reconcile this difference by accounting for the fundamental increase in carbon isotope fractionation by land plants in response to increasing atmospheric $\mathrm{CO}_{2}$ concentration $\left(p \mathrm{CO}_{2}\right)$. We show that for any change in $\mathrm{pCO}_{2}$ concentration $\left(\Delta p \mathrm{CO}_{2}\right)$, terrestrial and marine records can be used together to reconstruct background and maximum $p \mathrm{CO}_{2}$ levels across the carbon isotope excursion. When applied to the carbon isotope excursion at the Palaeocene-Eocene boundary, we calculate $\mathrm{pCO}_{2}=674-1,034$ p.p.m.v. during the Late Palaeocene and 1,384-3,342 p.p.m.v. during the height of the carbon isotope excursion across all sources postulated for the carbon release. This analysis demonstrates the need to account for changing $\mathrm{pCO}_{2}$ concentration when analysing large-scale changes in the carbon isotope composition of terrestrial substrates.

\footnotetext{
${ }^{1}$ University of Hawai'i at Mānoa, Department of Geology and Geophysics, Honolulu, Hawai'i 96822, USA. `Present address: School of Geosciences, University of Louisiana at Lafayette, 611 McKinley Street, Box 44530, Hamilton Hall \#323, Lafayette, Louisiana 70504, USA. Correspondence and requests for materials should be addressed to B.A.S. (email: schubert@louisiana.edu).
} 
G lobally correlated, negative excursions in carbon isotope $\left(\delta^{13} \mathrm{C}\right)$ values measured in marine and terrestrial substrates throughout the Phanerozoic indicate episodic, massive additions of isotopically depleted carbon to the oceanatmosphere system ${ }^{1-10}$. These events not only changed the carbon isotope composition of atmospheric carbon dioxide $\left(\delta^{13} \mathrm{C}_{\mathrm{CO} 2}\right)$, but also raised $p \mathrm{CO}_{2}$ concentrations (for example, ref. 11). The magnitude of the carbon isotope excursion (CIE) and the amount of $p \mathrm{CO}_{2}$ rise $\left(\Delta p \mathrm{CO}_{2}\right)$ calculated for such events should relate to one another, and the source of the carbon input and changes in the global carbon cycle have been reconstructed upon this premise (for example, refs 5,9,11,12). Determination of the 'true' magnitude of a CIE (that is, the amount of the CIE caused only by the change in $\delta^{13} \mathrm{C}_{\mathrm{CO} 2}$ ) is fundamental to calculating the amount of carbon added to the atmosphere at the event and improving our understanding of feedbacks in the climate system ${ }^{13,14}$.

One complicating factor is that the magnitude of the CIE is characteristically larger when measured in terrestrial versus marine substrates by up to several per mil ${ }^{6-9,11,15}$. Workers have argued that larger-magnitude negative excursions recorded in terrestrial substrates reflect increased humidity or precipitation $^{6,7}$ based on the increased carbon isotope fractionation that modern land plants demonstrate in response to these environmental factors. Others have attributed this difference to an increased abundance of angiosperm flora, which are characteristically isotopically depleted in comparison with gymnosperm flora ${ }^{16,17}$. Both of these mechanisms are problematic as general explanations for any global discrepancy between terrestrial and marine CIEs because their influences are most likely to be locally and heterogeneously expressed ${ }^{15,18}$ (Supplementary Information). Moreover, changes in angiosperm abundance cannot explain larger terrestrial versus marine CIEs in pre-Cretaceous substrates (for example, ref. 7). The reconciliation of terrestrial versus marine CIEs requires a mechanism fundamental to all $\mathrm{C}_{3}$ photosynthesis, and thus globally applicable (we note that classical $\mathrm{C}_{4}$ photosynthesis is a recent evolutionary innovation, relegated to no more than the last $\sim 13$ million years of Earth's history ${ }^{19,20}$, and that CAM photosynthesis is largely limited to aqueous and desert environments).

Previous experiments have shown that the carbon isotope value of plant tissues $\left(\delta^{13} \mathrm{C}_{\mathrm{p}}\right)$ is affected by changes in $p \mathrm{CO}_{2}$ concentration, independent of changes in $\delta^{13} \mathrm{C}_{\mathrm{CO}}$, and identified a positive relationship between $p \mathrm{CO}_{2}$ concentration and carbon isotope fractionation $\left(\Delta \delta^{13} \mathrm{C}_{\mathrm{p}} \approx \delta^{13} \mathrm{C}_{\mathrm{CO} 2}-\delta^{13} \mathrm{C}_{\mathrm{p}}\right)$ in both angiosperm and gymnosperm taxa (for example, refs 21,22; Supplementary Information). More recently, time-series correlations between climate variables and tree-ring $\Delta \delta^{13} C_{\mathrm{p}}$ values have been shown to improve when a correction proportional to the increase in $p \mathrm{CO}_{2}$ is applied (for example, refs 23-25). However, a wide range of corrections for the effect of changing $p \mathrm{CO}_{2}$ on $\Delta \delta^{13} \mathrm{C}_{\mathrm{p}}$ (S; \%o/p.p.m.v.) have been reported and applied, typically ranging from $S=0.73$ to $2.0 \%$ per 100 p.p.m.v. increase in $p \mathrm{CO}_{2}$ (for example, refs 23,24; Supplementary Information).

Our recent work growing plants under controlled environmental conditions across a wide range of $p \mathrm{CO}_{2}$ levels (up to 4,200 p.p.m.v.) provided a unifying relationship for the effect of $p \mathrm{CO}_{2}$ on $\mathrm{C}_{3}$ plant tissue, showing that $S$ decreases systematically with increasing $p \mathrm{CO}_{2}$ across a wide range of $\mathrm{C}_{3}$ plants $(R=0.96$, $n=33$ ) (Fig. 1) (ref. 26). This relationship suggests that for any large release of isotopically depleted carbon to the ocean or atmosphere, the land-plant-derived substrates of the terrestrial record $\left(\mathrm{CIE}_{\text {terrestrial; }}\right.$ that is, terrestrial organic matter, soil carbonate, plant lipids and tooth enamel) will record a largeramplitude CIE than marine substrates $\left(\mathrm{CIE}_{\text {marine; }}\right.$, that is, benthic

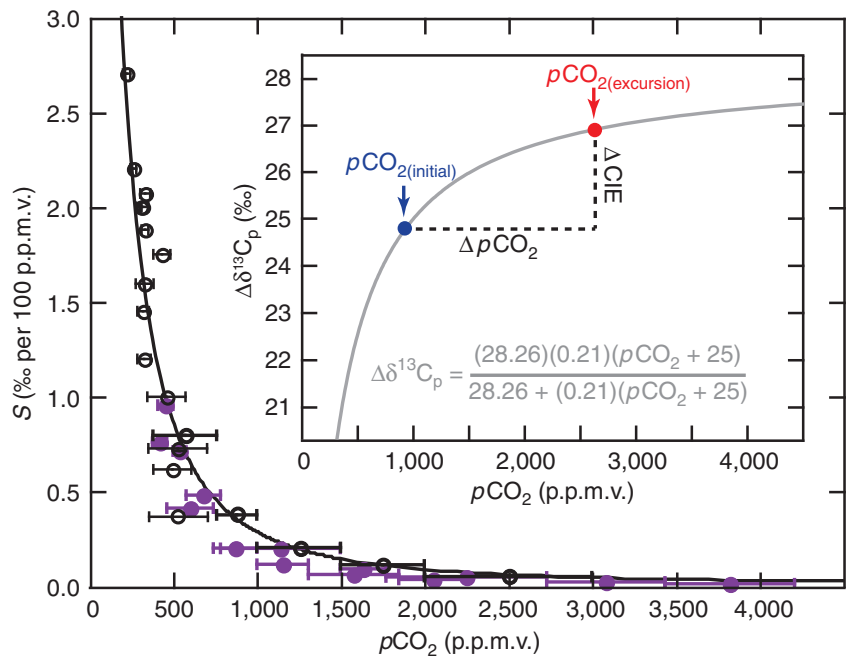

Figure 1 | The effect of $p \mathrm{CO}_{2}$ concentration on $\mathrm{C}_{3}$ land-plant carbon isotope fractionation. Across field and chamber experiments on a wide range of $\mathrm{C}_{3}$ land-plant species, the amount of carbon-isotope fractionation per change in $p \mathrm{CO}_{2}\left(\mathrm{~S}, \%\right.$ per p.p.m.v.) decreases within increasing $p \mathrm{CO}_{2}$ level according to the following equation: $S=(B)\left(A^{2}\right) /\left[A+B\left(p C \mathrm{O}_{2}+C\right)\right]^{2}$ with $R=0.96(n=33)$ (black curve), where $A=28.26, B=0.21$ and $C=25$. Purple closed circles reflect data from our experiments ${ }^{26}$; open black circles represent data compiled from published studies (Supplementary Table S2). Horizontal bars encompass the range of $p \mathrm{CO}_{2}$ levels used within each experiment; the circle is plotted at the midpoint of the range. The grey curve (inset) represents the integral of the black curve, and follows the general hyperbolic relationship: $\Delta \delta^{13} C_{p}=\left[(A)(B)\left(p C O_{2}+C\right)\right] /\left[A+(B)\left(p C O_{2}+C\right)\right]$ (see Supplementary Information). As the relationship between $p \mathrm{CO}_{2}$ and $\Delta \delta^{13} \mathrm{C}_{\mathrm{p}}$ is nonlinear, absolute estimates of $p \mathrm{CO}_{2 \text { (initial) (blue) and }}$ $p \mathrm{CO}_{2 \text { (excursion) }}$ (red) can be calculated by solving equations (1) and (2) provided $\triangle p \mathrm{CO}_{2}$ and $\Delta \mathrm{CIE}$ are known (dashed lines); for a given magnitude $\mathrm{CIE}$, the $\Delta p \mathrm{CO}_{2}$ estimate is dependent on the $\delta^{13} \mathrm{C}$ value of the source. Figure is modified from ref. 26 with new data reported in Lomax et al. ${ }^{59}$ (Supplementary Information; Supplementary Table S1).

foraminifera, planktic foraminifera and bulk marine carbonate). Thus, we propose that the difference in magnitude between these two substrates $\left(\triangle \mathrm{CIE}=\mathrm{CIE}_{\text {terrestrial }}-\mathrm{CIE}_{\text {marine }}\right)$ results from the additional fractionation by land plants due to rising $p \mathrm{CO}_{2}$ levels, which is then propagated within the terrestrial record. We apply this to the particularly well-studied and globally widespread CIE at the Palaeocene-Eocene Thermal Maximum (PETM), for which analysis of $>150$ CIEs shows a significant, $2.1 \%$ greater amplitude CIE recorded in terrestrial versus marine substrates ${ }^{11}$, in order to calculate absolute $p \mathrm{CO}_{2}$ levels during the Late Palaeocene and at the height of the CIE for the range of sources (and thus, $\Delta p \mathrm{CO}_{2}$ values) postulated for the carbon release.

\section{Results}

Reconciliation of $\Delta \mathrm{CIE}$ via the $p \mathrm{CO}_{2}$ effect. The larger-magnitude CIE recorded in terrestrial versus marine substrates can be described by the following equation relating $\triangle \mathrm{CIE}$ to the effect of changing $p \mathrm{CO}_{2}$ levels on carbon isotope fractionation by $\mathrm{C}_{3}$ land plants:

$$
\Delta \mathrm{CIE}=\frac{(A)(B)\left(p \mathrm{CO}_{2 \text { (initial })}+C\right)}{A+(B)\left(p \mathrm{CO}_{2(\text { initial })}+C\right)}-\frac{(A)(B)\left(p \mathrm{CO}_{2(\text { excursion })}+C\right)}{A+(B)\left(p \mathrm{CO}_{2(\text { excursion })}+C\right)}
$$

where $p \mathrm{CO}_{2 \text { (initial) }}$ and $p \mathrm{CO}_{2 \text { (excursion) }}$ are the $p \mathrm{CO}_{2}$ levels immediately before and at the height of the CIE, respectively, and $A, B$ and $C$ are constants produced by the best-fit curve through the 
experimental data and published values (Fig. 1 inset and Supplementary Information). For CIE events where the magnitude of both $\mathrm{CIE}_{\text {terrestrial }}$ and $\mathrm{CIE}_{\text {marine }}$ are well-documented globally, knowledge of $\triangle \mathrm{CIE}$ can be used towards the determination of both $p \mathrm{CO}_{2 \text { (initial) }}$ and $p \mathrm{CO}_{2 \text { (excursion) }}$ provided the change in $p \mathrm{CO}_{2}\left(\Delta p \mathrm{CO}_{2}\right)$ is known (Fig. 1 inset):

$$
\Delta p \mathrm{CO}_{2}=p \mathrm{CO}_{2 \text { (excursion) }}-p \mathrm{CO}_{2 \text { (initial) }}
$$

Estimates of $\Delta p \mathrm{CO}_{2}$, which are dependent on the true magnitude of the CIE and the $\delta^{13} \mathrm{C}$ value of the source $\left(\delta^{13} \mathrm{C}_{\text {source }}\right)$, are commonly calculated using methods ranging from mass balance equations (for example, refs 5,11) to numerical models (for example, refs 12,27). Therefore, provided independent estimates of $\Delta \mathrm{CIE}$ and $\Delta p \mathrm{CO}_{2}$, equations (1) and (2) can be solved simultaneously for absolute estimates of $p \mathrm{CO}_{2 \text { (initial) }}$ and $p \mathrm{CO}_{2 \text { (excursion) }}$ (Fig. 2), allowing for a wholly new quantitative reconstruction of changes in the global carbon cycle. Although determination of $p \mathrm{CO}_{2 \text { (initial) }}$ and $p \mathrm{CO}_{2 \text { (excursion) }}$ requires precise estimates of $\Delta \mathrm{CIE}$ and $\Delta p \mathrm{CO}_{2}$, Fig. 2 shows that the value for $p \mathrm{CO}_{2 \text { (initial) }}$ is more sensitive to $\Delta \mathrm{CIE}$ than to $\Delta p \mathrm{CO}_{2}$, while $p \mathrm{CO}_{2 \text { (excursion) }}$ is more sensitive to $\Delta p \mathrm{CO}_{2}$ than to $\Delta \mathrm{CIE}$.

Determination of $p \mathrm{CO}_{2}$ levels across the CIE at the PETM. The highly studied, globally widespread CIE that marks the PETM represents an ideal event upon which to first apply our methods to quantify $p \mathrm{CO}_{2 \text { (initial) }}$ and $p \mathrm{CO}_{2 \text { (excursion) }}$ because of the large number of $\mathrm{CIE}_{\text {terrestrial }}$ and $\mathrm{CIE}_{\text {marine }}$ records that can be used to provide a robust estimate of $\Delta \mathrm{CIE}$ globally. More than 150 total $\mathrm{CIE}_{\text {marine }}$ and $\mathrm{CIE}_{\text {terrestrial }}$ records have been measured across the PETM (reviewed by McInerney and Wing ${ }^{11}$ ); the average CIE measured in terrestrial substrates that include soil carbonate, plant lipids, bulk soil organic matter and tooth enamel $\left(\mathrm{CIE}_{\text {terrestrial }} \pm 1 \sigma=-4.7 \pm 1.5 \%\right.$ o, $\left.n=48\right)$ is $2.1 \%$ more negative than that measured in benthic foraminifera, planktic foraminifera and bulk marine carbonate from marine environments $\left(\mathrm{CIE}_{\text {marine }}\right.$ $\pm 1 \sigma=-2.6 \pm 1.1 \%, n=105)(\Delta \mathrm{CIE}=-2.1 \%)$. Bulk marine organic matter was not included in our determination of $\mathrm{CIE}_{\text {marine }}$ because it can include mixed pools of carbon from photosynthetic and non-photosynthetic organisms from terrestrial and marine environments ${ }^{15,28-30}$. By averaging across
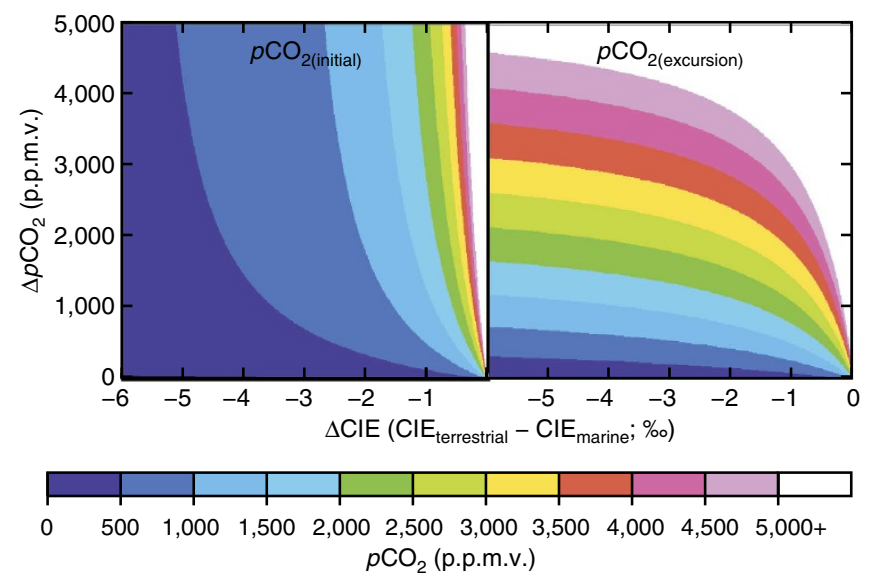

Figure 2 | Determination of $p \mathrm{CO}_{2}$ levels as a function of $\Delta \mathrm{CIE}$ and $\Delta p \mathrm{CO}_{2}$. For any hypothetical $\mathrm{CIE}, p \mathrm{CO}_{2 \text { (initial) }}$ (left) and $p \mathrm{CO}_{2 \text { (excursion) }}$ (right) are a function of the difference between the terrestrial and marine $\mathrm{CIE}(\triangle \mathrm{CIE}$; $\left.\Delta \mathrm{CIE}=\mathrm{ClE}_{\text {terrestrial }}-\mathrm{ClE}_{\text {marine }}\right)$ and the rise in $p \mathrm{CO}_{2}\left(\Delta p \mathrm{CO}_{2}\right.$; $\Delta p \mathrm{CO}_{2}=p \mathrm{CO}_{2 \text { (excursion) }}-p \mathrm{CO}_{2 \text { (initial) }}$ ). Values for $p \mathrm{CO}_{2 \text { (initial) }}$ and

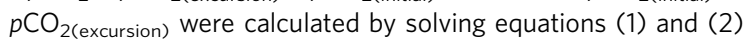
simultaneously. the large number of diverse sites and substrates available for the PETM, biasing effects of local and regional changes in climate $^{6,8,31-39}$, vegetation ${ }^{16,17,38}$, sediment transport $^{40,41}$, salinity ${ }^{15,42}$ and dissolution ${ }^{43,44}$ on $\triangle \mathrm{CIE}$ are limited. Using this $\Delta$ CIE value $(-2.1 \%)$, Late Palaeocene $\left(p \mathrm{CO}_{2 \text { (initial) }}\right)$ and PETM $\left(p \mathrm{CO}_{2 \text { (excursion) })}\right) p \mathrm{CO}_{2}$ levels can be determined across a range of $\Delta p \mathrm{CO}_{2}$ estimates by simultaneously solving equations (1) and (2) (Fig. 3).

Reconstructed estimates of $p \mathrm{CO}_{2 \text { (initial) }}$ and $p \mathrm{CO}_{2 \text { (excursion) }}$ increase as $\Delta p \mathrm{CO}_{2}$ increases (Fig. 3); thus the solution based on a methane hydrate source $\left(\delta^{13} \mathrm{C}_{\text {source }}=-60 \%, \Delta p \mathrm{CO}_{2}=\right.$ 710 p.p.m.v.) yielded the lowest Late Palaeocene $p \mathrm{CO}_{2}$ estimate $\left(p \mathrm{CO}_{2 \text { (initial) }}=674\right.$ p.p.m.v. $)$, followed by thermogenic methane or permafrost thawing $\left(\delta^{13} \mathrm{C}_{\text {source }}=-30 \%, \Delta p \mathrm{CO}_{2}=1,566\right.$ p.p.m.v. $)$ that yielded $p \mathrm{CO}_{2 \text { (initial) }}=915$ p.p.m.v., and then wildfire or drying of epicontinental seas $\left(\delta^{13} \mathrm{C}_{\text {source }}=-22 \%, \Delta p \mathrm{CO}_{2}=\right.$ 2,308 p.p.m.v.) having the highest Late Palaeocene $p \mathrm{CO}_{2}$ estimate $\left(p \mathrm{CO}_{2 \text { (initial) }}=1,034\right.$ p.p.m.v.). If these sources can be thought to exhaust the carbon isotope range of potential sources, we calculate that Late Palaeocene $p \mathrm{CO}_{2}$ levels may have been as low as $\sim 280$ p.p.m.v. higher than present, and were much lower than the recent $p \mathrm{CO}_{2}$ estimates for the year 2300 (refs 45,46; Fig. 3). $p \mathrm{CO}_{2}$ levels at the peak of the PETM were calculated to be 1,384 , 2,481 and 3,342 p.p.m.v. for methane hydrate, thermogenic methane or permafrost thawing, and drying of epicontinental seas or wildfire sources $\left(\Delta p \mathrm{CO}_{2}=710,1,566\right.$ and 2,308 p.p.m.v.), respectively (Fig. 3).

\section{Discussion}

Determination of Late Palaeocene and PETM $p \mathrm{CO}_{2}$ levels is important for quantifying climate sensitivity to $\mathrm{CO}_{2}$ for this greenhouse period (for example, ref. 47); however, previous proxy estimates for the Late Palaeocene are highly varied, ranging from 100 to 2,400 p.p.m.v., and robust PETM $p \mathrm{CO}_{2}$ estimates are lacking (Supplementary Information; Fig. 3). Across a wide range of increases in $p \mathrm{CO}_{2}$ at the PETM $\left(\Delta p \mathrm{CO}_{2} \leq 3,000\right.$ p.p.m.v. $)$, our results indicate that Late Palaeocene $p \mathrm{CO}_{2}$ levels were $\leq 1,112$ p.p.m.v. (Fig. 3 ). If we consider a relatively small increase in $p \mathrm{CO}_{2}$ levels $\left(\Delta p \mathrm{CO}_{2}<1,000\right.$ p.p.m.v. $)$, as would be attributed to a methane hydrate source, our Late Palaeocene $p \mathrm{CO}_{2}$ estimates are consistent with values determined from liverwort, phytoplankton and stomatal proxies (Fig. 3). The boron isotope proxy, in contrast, is more consistent with our results assuming that the amount of $p \mathrm{CO}_{2}$ increase was larger ( $>1,000$ p.p.m.v.), as would be required for the thawing permafrost model, for example (Fig. 3).

Although our reconciliation does not allow for the determination of the carbon source of the CIE at the PETM, recent work indicates significant warming before the onset of the CIE (refs 33,48), and suggests an orbitally forced mechanism for the release of carbon at the event ${ }^{49-51}$. If we consider the two hypotheses suggesting that orbital forcing triggered the release of carbon through a methane hydrate release (ref. 49) $\left(\Delta p \mathrm{CO}_{2}=710\right.$ p.p.m.v.) or large-scale thawing of permafrost (ref. 50) $\left(\Delta p \mathrm{CO}_{2}=1,566\right.$ p.p.m.v.), we calculate Late Palaeocene $p \mathrm{CO}_{2}$ levels $=674(+159-109)$ or $915(+225-153)$ p.p.m.v., respectively (error based on $\Delta \mathrm{CIE}=-1.6$ to $-2.6 \%$; Fig. 3). Notably, these calculated values for Late Palaeocene $p \mathrm{CO}_{2}$ are consistent with the $p \mathrm{CO}_{2}$ levels required by Lunt et al. ${ }^{49}$ ( 560 p.p.m.v.) and DeConto et al. ${ }^{50}$ ( 900 p.p.m.v.) for each of their respective models.

Many arguments have been made to explain the larger CIE measured in terrestrial versus marine substrates at the PETM $^{6,8,15-18,42,43}$, but each requires additional phenomena secondary to the carbon release (Supplementary Information). 


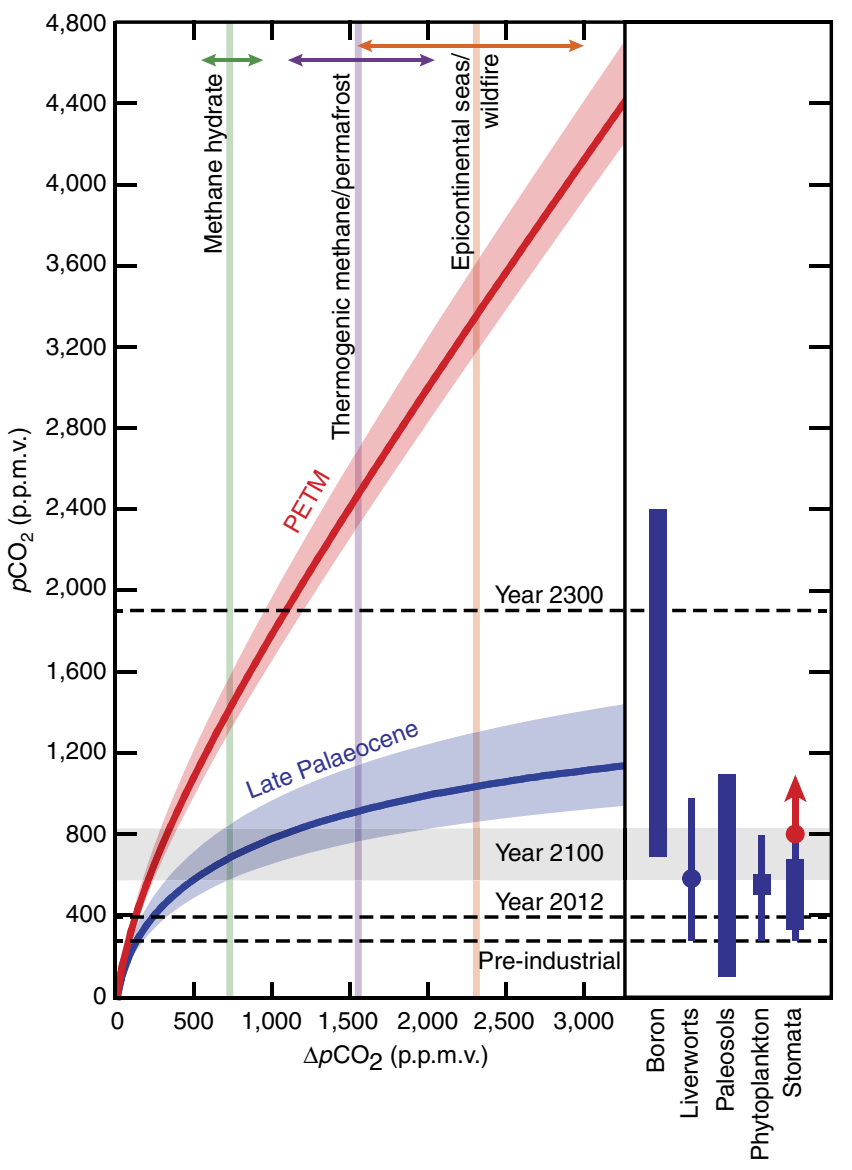

Figure 3 | Reconstruction of $p \mathrm{CO}_{2}$ levels during the Late Palaeocene and PETM. Across a range of possible $p \mathrm{CO}_{2}$ increases $\left(\Delta p \mathrm{CO}_{2}\right), p \mathrm{CO}_{2}$ levels for the Late Palaeocene (blue curve; $p \mathrm{CO}_{2 \text { (initial) }}$ ) and PETM (red curve; $p \mathrm{CO}_{2 \text { (excursion) }}$ ) were calculated by simultaneously solving equations (1) and (2) for $\Delta p \mathrm{CO}_{2}=0-3,600$ p.p.m.v. and $\Delta \mathrm{CIE}=-2.1 \%$ (thick curves). Blue and red shaded regions show solutions for $\Delta \mathrm{CIE}=-1.6$ to $-2.6 \%$ to illustrate the effect of $\Delta \mathrm{CIE}$ on $p \mathrm{CO}_{2}$ estimates (for a given $\Delta p \mathrm{CO}_{2}$, lower $\Delta \mathrm{CIE}$ values yield higher $p \mathrm{CO}_{2}$ estimates and vice versa). $\Delta \mathrm{CIE}=-2.5 \%$ assumes that $n$-alkanes $(\mathrm{CIE}=-5.1 \%$; ref. 11$)$ best represent $\mathrm{CIE}_{\text {terrestriali }}$ $\Delta \mathrm{CIE}=-1.6 \%$ suggests a smaller offset between $\mathrm{CIE}_{\text {terrestrial }}$ and $\mathrm{CIE}_{\text {marine }}$ owing to an underestimation of the magnitude of $\mathrm{CIE}_{\text {marine }}$

$\left(\mathrm{CIE}_{\text {marine }}=-3.1 \%\right.$ versus $-2.6 \%$ ). Vertical lines mark $\Delta p \mathrm{CO}_{2}$ estimates for specific proposed sources of the event (green $=$ methane hydrate ${ }^{14}$, $\delta^{13} \mathrm{C}_{\text {source }}=-60 \%$; purple $=$ thermogenic methane $\mathrm{e}^{54}$ or permafrost thawing ${ }^{50}, \delta^{13} \mathrm{C}_{\text {source }}=-30 \%$; and orange $=$ wildfire burning ${ }^{55}$ or oxidation of organic matter from drying of epicontinental seas ${ }^{56}$, $\delta^{13} C_{\text {source }}=-22 \%$ ) based on a mass balance equation (equation ( 3 ) and the parameters used by Mclnerney and Wing ${ }^{11}$ (0.3 p.p.m.v. increase in $\mathrm{pCO}_{2}$ per $\mathrm{PgC}$ added, $\delta^{13} \mathrm{C}_{\text {initial }}=-2.5 \%$, and $M_{\text {initial }}=50,000 \mathrm{Pg} \mathrm{C}$ ); horizontal arrows mark the range of $\Delta p \mathrm{CO}_{2}$ estimates calculated for each source (equation (3)), provided a range of estimates for the $\mathrm{pCO}_{2}$ increase per $\mathrm{Pg} \mathrm{C}$ added ( 0.23 to 0.39 ) and estimates of $\delta^{13} \mathrm{C}_{\text {initial }}(-2.5$ to $-0.1 \%$ ) (Methods). The range of average Late Palaeocene (60-55Ma) $p \mathrm{CO}_{2}$ estimates from other proxies (blue bars) are indicated; a single $p \mathrm{CO}_{2}$ estimate from stomata provides a lower bound on $\mathrm{PCO}_{2}$ during the PETM (red point and arrow) (references are provided in the Supplementary Information). Dashed lines mark pre-industrial (280 p.p.m.v.) and presentday (393 p.p.m.v.) $p \mathrm{CO}_{2}$ levels, as well as a model-based projection of $p \mathrm{CO}_{2}$ in the year 2300 if fossil fuel burning continues unabated (1,900 p.p.m.v.) (ref. 46). Grey-shaded region represents the range of $\mathrm{pCO}_{2}$ projections for the year 2100 from the IPCC (566-821 p.p.m.v.) (ref. 60).
Based on the fundamental observation of increased carbon isotope fractionation in $\mathrm{C}_{3}$ land plants in response to elevated $p \mathrm{CO}_{2}$ levels (Fig. 1), we propose that the larger amplitude CIE recorded in terrestrial substrates results from the primary phenomenon of rising $p \mathrm{CO}_{2}$ levels. We attribute deviations from the average size of the CIE measured on the same substrate at different sites to local or regional changes in water availability $6,8,18,36$, plant composition $^{16,17,38,52}$, dissolution ${ }^{43}$ and salinity ${ }^{42}$. For these reasons, the average of many CIEs measured across the planet should be used to determine the average magnitude of the marine and terrestrial signals for the purpose of reconciling the magnitude of the event and reconstructing $\mathrm{pCO}_{2}$ levels.

We further note systematic differences in the magnitude of the CIE within the marine and terrestrial substrates as compiled by McInerney and Wing ${ }^{11}$ in their Table 1 . Within the marine record, foraminifera (benthic and planktonic) and bulk marine carbonate record the smallest CIE $(-2.5$ to $-2.7 \%$ ), while algal lipids and bulk marine organic matter record a greater CIE $(-3.5$ to $-4.1 \%$ ). In terrestrial systems, the smallest CIE is measured in bulk soil organic matter $(-3.5 \%)$, followed by tooth enamel and plant lipids $(-4.8$ to $-5.1 \%$ ), with the largest CIE measured in soil carbonate $(-5.5 \%$ ). The greater CIE measured in algal lipids compared with foraminifera is likely caused by elevated $p \mathrm{CO}_{2}$ levels, as photosynthetic algae are also known to show increasing carbon isotope fractionation with increasing concentrations of $\mathrm{CO}_{2}$ dissolved in water although these relationships vary widely (reviewed within ref. 53) and differ from that of higher land plants. Bulk organic matter in terrestrial and marine environments show the same median magnitude CIE ( $-3.5 \%)$; the CIE measured in terrestrial bulk organic matter may be dampened relative to other terrestrial substrates by mixing of organic matter of a different age ${ }^{15}$, while the marine bulk organic matter CIE is likely augmented compared with other marine substrates by photosynthetic inputs from terrestrial and marine environments ${ }^{15,28-30}$. Variability in the degree of these inputs may explain why bulk marine organic matter shows the greatest variability among all substrates $(1 \sigma= \pm 2.2 \%$ ). Within purely terrestrial systems, the median CIE recorded in plant lipids $\left(-5.0 \%\right.$ ) reflects the full effects of elevated $p \mathrm{CO}_{2}$ levels on plant isotope fractionation (as shown here and in ref. 26); the similar median CIE recorded in fossil tooth enamel $(-4.9 \%$ ) is not surprising considering that it reflects the $\delta^{13} \mathrm{C}$ value of the plants the herbivore consumes. The very large CIE measured in paleosol carbonate (average $=-5.5 \%$, median $=-6.3 \%$ ) may reflect a combination of the enhanced fractionation by plants under high $p \mathrm{CO}_{2}$, diffusion of increased $p \mathrm{CO}_{2}$ levels into the soil and increased productivity. Based on measurements of enamel carbonate, Secord et al. ${ }^{33}$ attribute $1.5 \%$ of the CIE measured in soil carbonate to increased rates of carbon turnover, driven by warmer climate.

Our results illustrate the need to account for changes in $p \mathrm{CO}_{2}$ concentration when interpreting changes in the carbon isotope composition of substrates derived at least in part from $\mathrm{C}_{3}$ land plants, which dominate the terrestrial carbon record. Although our analysis was applied specifically to the PETM, the fundamental $p \mathrm{CO}_{2}$ effect and equations presented here can be applied similarly to other global CIE events recorded in marine and terrestrial sediments (for example, Aptian-Albian, Early Toarcian, Triassic-Jurassic, Permian-Triassic and many others) in order to quantitatively reconstruct levels of $p \mathrm{CO}_{2}$ before and during the CIE event.

\section{Methods}

Quantifying $\Delta p \mathrm{CO}_{2}$. We used the following mass balance equation modified from McInerney and Wing ${ }^{11}$ to quantify $\Delta p \mathrm{CO}_{2}$ for each of the proposed sources (vertical, coloured lines in Fig. 3: green $=$ methane hydrate $e^{14}, \delta^{13} \mathrm{C}_{\text {source }}=-60 \%$; purple $=$ thermogenic methane ${ }^{54}$ or permafrost thawing $g^{50}, \delta^{13} \mathrm{C}_{\text {source }}=-30 \%$; 
and orange $=$ wildfire burning ${ }^{55}$ or oxidation of organic matter from drying of epicontinental seas ${ }^{56}, \delta^{13} \mathrm{C}_{\text {source }}=-22 \%$ ):

$$
\Delta p \mathrm{CO}_{2}=\frac{-\left(\mathrm{CIE}_{\text {marine }}\right)\left(M_{\text {initial }}\right)(0.3)}{\delta^{13} \mathrm{C}_{\text {final }}-\delta^{13} \mathrm{C}_{\text {source }}}
$$

where $M_{\text {inital }}$ is the mass of the Palaeocene surface reservoir, $\delta^{13} \mathrm{C}_{\text {final }}$ is the $\delta^{13} \mathrm{C}$ value at the PETM $\left(\delta^{13} \mathrm{C}_{\text {final }}=\delta^{13} \mathrm{C}_{\text {initial }}+\mathrm{CIE}_{\text {marine }}\right), \delta^{13} \mathrm{C}_{\text {initial }}$ is the $\delta^{13} \mathrm{C}$ value of the Late Palaeocene carbon pool and $\delta^{13} \mathrm{C}_{\text {source }}$ is the $\delta^{13} \mathrm{C}$ value of the source responsible for the $\mathrm{CIE}$. We used $\mathrm{CIE}_{\text {marine }}$ (and not $\mathrm{CIE}_{\text {terrestrial }}$ ) because it does not incorporate any land-plant-derived components and thus only represents changes in $\delta^{13} \mathrm{C}_{\mathrm{CO} 2}$. The constant 0.3 indicates that for every $1 \mathrm{Pg} \mathrm{C}$ added $p \mathrm{CO}_{2}$ increases 0.3 p.p.m.v. (ref. 11); this value is within the range of values suggested from models of the carbon release at the PETM (for example, 0.23-0.39; refs $12,27,57)$. We calculated the value for $\operatorname{CIE}_{\text {marine }}(-2.6 \%)$ as the average of the CIEs measured in benthic forams $(-2.5 \pm 1.0 \%, n=36)$, planktic forams $(-2.7 \pm 1.0 \%, n=36)$ and bulk marine carbonate $(-2.7 \pm 1.1 \%, n=33)$ as listed in Table 1 of McInerney and Wing ${ }^{11}$. Bulk marine organic matter ( $\mathrm{CIE}=-4.1 \pm 2.2 \%$ o, $n=11$ ) was not included in the average because it may contain a mix of marine and terrestrial inputs ${ }^{28-30}$; the single CIE measured on algal lipids ( $\mathrm{CIE}=-3.5 \%$ ) was also excluded. Our values for $M_{\text {initial }}=50,000 \mathrm{Pg} \mathrm{C}$ and $\delta^{13} C_{\text {initial }}=-2.5 \%$ were based on the values used by McInerney and Wing ${ }^{11}$. We note, however, that the value for $\delta^{13} \mathrm{C}_{\text {initial }}=-2.5 \%$ may be too low; we estimate $\delta^{13} C_{\text {initial }}$ as high as $-0.1 \%$ assuming a pre-industrial value of -2.1 to $-2.6 \%$ (ref. 14) offset by $+2.0 \%$ based on the secular change in $\delta^{13} \mathrm{C}$ (ref. 58 ).

\section{References}

1. Hesselbo, S. P., Robinson, S. A., Surlyk, F. \& Piasecki, S. Terrestrial and marine extinction at the Triassic-Jurassic boundary synchronized with major carbon-cycle perturbation: a link to initiation of massive volcanism? Geology 30, 251-254 (2002).

2. Koch, P. L., Zachos, J. C. \& Gingerich, P. D. Correlation between isotope records in marine and continental carbon reservoirs near the Palaeocene/ Eocene boundary. Nature 358, 319-322 (1992).

3. Hesselbo, S. P. et al. Carbon-cycle perturbation in the Middle Jurassic and accompanying changes in the terrestrial paleoenvironment. J. Geol. 111, 259-276 (2003)

4. Herrle, J. O., Kößler, P., Friedrich, O., Erlenkeuser, H. \& Hemleben, C. High-resolution carbon isotope records of the Aptian to Lower Albian from SE France and the Mazagan Plateau (DSDP Site 545): a stratigraphic tool for paleoceanographic and paleobiologic reconstruction. Earth Planet Sci. Lett. 218, 149-161 (2004).

5. Ruhl, M., Bonis, N. R., Reichart, G.-J., Damsté, J. S. S. \& Kürschner, W. M. Atmospheric carbon injection linked to end-Triassic mass extinction. Science 333, 430-434 (2011).

6. Bowen, G. J., Beerling, D. J., Koch, P. L., Zachos, J. C. \& Quattlebaum, T. A humid climate state during the Palaeocene/Eocene thermal maximum. Nature 432, 495-499 (2004).

7. Hesselbo, S. P., Jenkyns, H. C., Duarte, L. V. \& Oliveira, L. C. V. Carbonisotope record of the Early Jurassic (Toarcian) Oceanic Anoxic Event from fossil wood and marine carbonate (Lusitanian Basin, Portugal). Earth Planet Sci. Lett. 253, 455-470 (2007).

8. Abels, H. A. et al. Terrestrial carbon isotope excursions and biotic change during Palaeogene hyperthermals. Nat. Geosci. 5, 326-329 (2012).

9. Jahren, A. H., Conrad, C. P., Arens, N. C., Mora, G. \& Lithgow-Bertelloni, C. A plate tectonic mechanism for methane hydrate release along subduction zones. Earth Planet Sci. Lett. 236, 691-704 (2005).

10. Tipple, B. J. et al. Coupled high-resolution marine and terrestrial records of carbon and hydrologic cycles variations during the Paleocene-Eocene Thermal Maximum (PETM). Earth Planet Sci. Lett. 311, 82-92 (2011).

11. McInerney, F. A. \& Wing, S. L. The Paleocene-Eocene thermal maximum: a perturbation of carbon cycle, climate, and biosphere with implications for the future. Annu. Rev. Earth Planet Sci. 39, 489-516 (2011).

12. Zeebe, R. E., Zachos, J. C. \& Dickens, G. R. Carbon dioxide forcing alone insufficient to explain Palaeocene-Eocene Thermal Maximum warming. Nat. Geosci. 2, 576-580 (2009).

13. Pagani, M., Caldeira, K., Archer, D. \& Zachos, J. C. An ancient carbon mystery. Science 314, 1556-1557 (2006).

14. Dickens, G. R., O’Neil, J. R., Rea, D. K. \& Owen, R. M. Dissociation of oceanic methane hydrate as a cause of the carbon isotope excursion at the end of the Paleocene. Paleoceanography 10, 965-971 (1995).

15. Sluijs, A. \& Dickens, G. R. Assessing offsets between the $\delta^{13} \mathrm{C}$ of sedimentary components and the global exogenic carbon pool across early Paleogene carbon cycle perturbations. Global Biogeochem. Cycles 26 10.1029/2011GB004224 doi:10.1029/2011gb004224 (2012).

16. Schouten, S. et al. The Paleocene-Eocene carbon isotope excursion in higher plant organic matter: differential fractionation of angiosperms and conifers in the Arctic. Earth Planet Sci. Lett. 258, 581-592 (2007).
17. Smith, F. A., Wing, S. L. \& Freeman, K. H. Magnitude of the carbon isotope excursion at the Paleocene-Eocene thermal maximum: the role of plant community change. Earth Planet Sci. Lett. 262, 50-65 (2007).

18. Pagani, M. et al. Arctic hydrology during global warming at the Palaeocene/ Eocene thermal maximum. Nature 442, 671-675 (2006).

19. Kohn, M. J. Carbon isotope compositions of terrestrial C3 plants as indicators of (paleo)ecology and (paleo)climate. Proc. Natl Acad. Sci. USA 107, 19691-19695 (2010).

20. Edwards, G. E., Furbank, R. T., Hatch, M. D. \& Osmond, C. B. What does it take to be $\mathrm{C}_{4}$ ? Lessons from the evolution of $\mathrm{C}_{4}$ photosynthesis. Plant Physiol. 125, 46-49 (2001).

21. Feng, X. \& Epstein, S. Carbon isotopes of trees from arid environments and implications for reconstructing atmospheric $\mathrm{CO}_{2}$ concentration. Geochim. Cosmochim. Acta 59, 2599-2608 (1995).

22. Kürschner, W. M. Leaf Stomata as Biosensors of Palaeoatmospheric $\mathrm{CO}_{2}$ Levels $\mathrm{PhD}$ Thesis, Utrecht University (1996).

23. Wang, W. et al. A 200 year temperature record from tree ring $\delta^{13} \mathrm{C}$ at the Qaidam Basin of the Tibetan Plateau after identifying the optimum method to correct for changing atmospheric $\mathrm{CO}_{2}$ and $\delta^{13} \mathrm{C}$. J. Geophys. Res. 116, G04022 (2011).

24. Treydte, K. S. et al. Impact of climate and $\mathrm{CO}_{2}$ on a millennium-long tree-ring carbon isotope record. Geochim. et Cosmochim. Acta 73, 4635-4647 (2009).

25. McCarroll, D. et al. Correction of tree ring stable isotope chronologies for changes in the carbon dioxide content of the atmosphere. Geochim. et Cosmochim. Acta 73, 1539-1547 (2009).

26. Schubert, B. A. \& Jahren, A. H. The effect of atmospheric $\mathrm{CO}_{2}$ concentration on carbon isotope fractionation in $\mathrm{C}_{3}$ land plants. Geochim. et Cosmochim. Acta 96, 29-43 (2012).

27. Cui, Y. et al. Slow release of fossil carbon during the Palaeocene-Eocene thermal maximum. Nat. Geosci. 4, 481-485 (2011).

28. Schoon, P. L., Sluijs, A., Damsté, J. S. S. \& Schouten, S. Stable carbon isotope patterns of marine biomarker lipids in the Arctic Ocean during Eocene Thermal Maximum 2. Paleoceanography 26, PA3215 (2011).

29. Weijers, J. W. H., Schouten, S., Schefuß, E., Schneider, R. R. \& Sinninghe Damsté, J. S. Disentangling marine, soil and plant organic carbon contributions to continental margin sediments: a multi-proxy approach in a 20,000 year sediment record from the Congo deep-sea fan. Geochim. et Cosmochim. Acta 73, 119-132 (2009).

30. Gordon, E. S. \& Goñi, M. A. Sources and distribution of terrigenous organic matter delivered by the Atchafalaya River to sediments in the northern Gulf of Mexico. Geochim. et Cosmochim. Acta 67, 2359-2375 (2003).

31. Schmitz, B. \& Pujalte, V. Abrupt increase in seasonal extreme precipitation at the Paleocene-Eocene boundary. Geology 35, 215-218 (2007).

32. Wing, S. L. et al. Transient floral change and rapid global warming at the Paleocene-Eocene boundary. Science 310, 993-996 (2005).

33. Secord, R., Gingerich, P. D., Lohmann, K. C. \& MacLeod, K. G. Continental warming preceding the Palaeocene-Eocene thermal maximum. Nature 467, 955-958 (2010).

34. Larrasoaña, J. C. et al. Magnetotactic bacterial response to Antarctic dust supply during the Palaeocene-Eocene thermal maximum. Earth Planet Sci. Lett. 333-334, 122-133 (2012).

35. Kraus, M. J. \& Riggins, S. Transient drying during the Paleocene-Eocene Thermal Maximum (PETM): analysis of paleosols in the bighorn basin, Wyoming. Palaeogeogr. Palaeoclimatol. Palaeoecol. 245, 444-461 (2007).

36. Handley, L. et al. Changes in the hydrological cycle in tropical East Africa during the Paleocene-Eocene Thermal Maximum. Palaeogeogr. Palaeoclimatol. Palaeoecol. 329-330, 10-21 (2012).

37. Storme, J. Y. et al. Cycles of humid-dry climate conditions around the P/E boundary: new stable isotope data from terrestrial organic matter in Vasterival section (NW France). Terr. Nova 24, 114-122 (2012).

38. Diefendorf, A. F., Mueller, K. E., Wing, S. L., Koch, P. L. \& Freeman, K. H. Global patterns in leaf ${ }^{13} \mathrm{C}$ discrimination and implications for studies of past and future climate. Proc. Natl Acad. Sci. USA 107, 5738-5743 (2010).

39. Winguth, A., Shellito, C., Shields, C. \& Winguth, C. Climate response at the Paleocene-Eocene Thermal Maximum to greenhouse gas forcing-A model study with CCSM3. J. Clim. 23, 2562-2584 (2010).

40. John, C. M. et al. Clay assemblage and oxygen isotopic constraints on the weathering response to the Paleocene-Eocene thermal maximum, east coast of North America. Geology 40, 591-594 (2012).

41. Foreman, B. Z., Heller, P. L. \& Clementz, M. T. Fluvial response to abrupt global warming at the Palaeocene/Eocene boundary. Nature 491, 92-95 (2012).

42. Dickens, G. R. Down the rabbit hole: toward appropriate discussion of methane release from gas hydrate systems during the Paleocene-Eocene thermal maximum and other past hyperthermal events. Clim. Past 7, 831-846 (2011).

43. Zachos, J. C. et al. Rapid acidification of the ocean during the Paleocene-Eocene thermal maximum. Science 308, 1611-1615 (2005). 
44. McCarren, H., Thomas, E., Hasegawa, T., Röhl, U. \& Zachos, J. C. Depth dependency of the Paleocene-Eocene carbon isotope excursion: paired benthic and terrestrial biomarker records (Ocean Drilling Program Leg 208, Walvis Ridge). Geochem. Geophys. Geosyst. 9, Q10008 (2008).

45. Zachos, J. C., Dickens, G. R. \& Zeebe, R. E. An early Cenozoic perspective on greenhouse warming and carbon-cycle dynamics. Nature 451, 279-283 (2008).

46. Caldeira, K. \& Wickett, M. E. Anthropogenic carbon and ocean pH. Nature 425, 365 (2003)

47. Royer, D. L., Pagani, M. \& Beerling, D. J. Geobiological constraints on earth system sensitivity to $\mathrm{CO}_{2}$ during the Cretaceous and Cenozoic. Geobiology 10, 298-310 (2012).

48. Sluijs, A. et al. Environmental precursors to rapid light carbon injection at the Palaeocene/Eocene boundary. Nature 450, 1218-1221 (2007).

49. Lunt, D. J. et al. A model for orbital pacing of methane hydrate destabilization during the Palaeogene. Nat. Geosci. 4, 775-778 (2011).

50. DeConto, R. M. et al. Past extreme warming events linked to massive carbon release from thawing permafrost. Nature 484, 87-92 (2012).

51. Lourens, L. J. et al. Astronomical pacing of late Palaeocene to early Eocene global warming events. Nature 435, 1083-1087 (2005).

52. Diefendorf, A. F., Freeman, K. H., Wing, S. L. \& Graham, H. V. Production of $\mathrm{n}$-alkyl lipids in living plants and implications for the geologic past. Geochim. et Cosmochim. Acta 75, 7472-7485 (2011).

53. Royer, D. L., Berner, R. A. \& Beerling, D. J. Phanerozoic atmospheric $\mathrm{CO}_{2}$ change: evaluating geochemical and paleobiological approaches. Earth Sci. Rev. 54, 349-393 (2001).

54. Svensen, H. et al. Release of methane from a volcanic basin as a mechanism for initial Eocene global warming. Nature 429, 542-545 (2004).

55. Kurtz, A. C., Kump, L. R., Arthur, M. A., Zachos, J. C. \& Paytan, A. Early Cenozoic decoupling of the global carbon and sulfur cycles. Paleoceanography 18, doi:10.1029/2003pa000908 (2003).

56. Higgins, J. A. \& Schrag, D. P. Beyond methane: towards a theory for the Paleocene-Eocene Thermal Maximum. Earth Planet Sci. Lett. 245, 523-537 (2006).
57. Panchuk, K., Ridgwell, A. \& Kump, L. R. Sedimentary response to PaleoceneEocene Thermal Maximum carbon release: a model-data comparison. Geology 36, 315-318 (2008).

58. Tipple, B. J., Meyers, S. R. \& Pagani, M. Carbon isotope ratio of Cenozoic $\mathrm{CO}_{2}$ : a comparative evaluation of available geochemical proxies. Paleoceanography 25, doi:10.1029/2009pa001851 (2010).

59. Lomax, B. H., Knight, C. A. \& Lake, J. A. An experimental evaluation of the use of $\mathrm{C}_{3} \delta^{13} \mathrm{C}$ plant tissue as a proxy for the paleoatmospheric $\delta^{13} \mathrm{CO}_{2}$ signature of air. Geochem. Geophys. Geosyst. 13, Q0AI03 (2012).

60. IPCC. Climate Change 2001: Synthesis Report. IPCC, 2001.

\section{Acknowledgements}

This work was supported by DOE/BES Grant DE-FG02-09ER16002.

\section{Author contributions}

B.A.S. and A.H.J. wrote the paper and analysed the results; B.A.S. developed the equations and methods with advice and assistance from A.H.J.

\section{Additional information}

Supplementary Information accompanies this paper at http://www.nature.com/ naturecommunications

Competing financial interests: The authors claim no competing financial interests associated with this paper.

Reprints and permission information is available online at http://npg.nature.com/ reprintsandpermissions/

How to cite this article: Schubert, B. A. \& Jahren, A. H. Reconciliation of marine and terrestrial carbon isotope excursions based on changing atmospheric $\mathrm{CO}_{2}$ levels Nat. Commun. 4:1653 doi: 10.1038/ncomms2659 (2013). 